\title{
DAKWAH MULTIKULTURAL PESANTREN NGALAH DALAM MEREDAM RADIKALISME AGAMA
}

\author{
Saifulah \\ Universitas Yudharta Pasuruan, Indonesia \\ E-mail: sayf-allah@yahoo.com
}

\begin{abstract}
The emergence of radical ideology and violent movement that employ terror as a means to achieve goals has become prevalent in today's life. This has been the subject matter widely discussed by a great deal of scholars, Muslims and non-Muslims alike. Among Muslims themselves, such a phenomenon raises anxieties. If this is not taken care of appropriately, it will have a negative impact on humanity, particularly Muslims who live in Muslim minority countries where Islamophobia is widespread. Along with this, pesantren as one of the oldest Muslim institutions of learning has a significant role in eliminating radicalism and terrorism in the name of religion. As far as the writer is concerned, efforts at dealing with radicalism have not been conducted seriously, although some pesantren have taken part in such projects. This paper tries to offer an alternative solution to eradicate religious radicalism and terrorism based on the experiences of Pesantren Ngalah by implementing the strategy of multicultural learning.
\end{abstract}

Keywords: Pesantren, multicultural preaching, religious radicalism.

\section{Pendahuluan}

Dalam diskursus perkembangan pemikiran Islam kontemporer, isu terorisme, radikalisme agama, multikulturalisme, dan pluralisme menjadi isu penting dalam dua dasawarsa terakhir ini. Diskursus tersebut menjadi semakin aktual jika mengaitkan pesantren dengan pola dakwahnya. Ada beberapa argumentasi mendasar yang dapat diajukan untuk menjelaskannya, di antaranya adalah bahwa dalam struktur kekerasan yang diproduksi oleh sistem sosial globalisasi 
dengan wataknya yang dominatif, hegemonik, dan eksploitatif, ${ }^{1}$ hampir dapat dipastikan elemen keagamaan berada di dalamnya.

Banyak kasus yang dapat dirujuk, seperti tragedi 11 September 2001, yang menjadi musibah mengerikan umat manusia di seluruh dunia. Umat Islam juga merasa tersudutkan karena pelakunya mengaku seorang Muslim. Tentu hal ini telah memunculkan sejumlah pertanyaan di pikiran banyak orang Barat tentang hubungan kesucian dan kekerasan dalam Islam. Parahnya, para akademisi Barat telah terlampau jauh mengklaim bahwa doktrin kekerasan juga diajarkan dalam al-Qur'ân. ${ }^{2}$ Sementara fenomena radikalisme dan terorisme ${ }^{3}$ yang mengatasnamakan Islam semakin meluas dan tumbuh subur di beberapa negara, termasuk Indonesia. Potret lembaga keagamaan seperti pesantren pun tidak luput dari sorotan, karena di antara para oknum pelaku teror rata-rata memang pernah mengenyam pendidikan di pondok pesantren. Salah satu kasus yang paling diingat adalah kasus Bom Bali I dan II yang pelakunya adalah sebagian alumni Pesantren Ngruki, Solo. Kasus pesantren Umar bin Khattab di Bima Nusa Tenggara Barat yang dijadikan sarang radikalisme dan terorisme juga merusak citra pesantren, sehingga tidak mengherankan pada waktu itu banyak para pengamat terorisme dan radikalisme yang menyebutkan bahwa pondok pesantren adalah sarang terorisme. Pendapat tersebut tentu saja tidak dapat dibenarkan, karena menggeneralisir semua lembaga pondok pesantren.

Isu terorisme dan radikalisme ini telah memengaruhi kaca pandang masyarakat terhadap pesantren. Walaupun demikian, sedikitbanyak, isu terorisme dan radikalisme sebenarnya memacu semangat baru bagi pesantren untuk melakukan introspeksi diri untuk mereaktualisir kajian Islam terkait isu-isu kekinian, terutama terkait isu terorisme dan radikalisme. Kajian-kajian di dalamnya tentu saja diarahkan pada gagasan pendidikan multikultural sebagai landasan

${ }^{1}$ Mansour Fakih, Runtubnya Teori Pembangunan dan Globalisasi (Yogyakarta: Pustaka Pelajar dan Insist, 2002), 182-204.

2 Ibrahim M. Abu Rabi', "Post-September 11 Critical Assement of Modern Islamic History", dalam 11 September: Religious Perspectives on the Causes and Consequences (England: Oneword Publications, 2002), 22.

${ }^{3}$ Fenomena radikalisme dan terorisme sebagaimana yang dijelaskan oleh Abdullah Saeed sebagai kelompok The Islamist Extremists salah satu tren pemikiran Islam kontemporer. Kelompok ini adalah kelompok militan yang melakukan propaganda anti-Barat, mereka meyakini dengan menggunakan teror untuk dapat mencapai tujuan. Lihat Abdullah Saeed, Islamic Thought: An Introduction (London dan New York: Routledge, 2006), 148. 
budaya, terkait erat dengan pencapaian bagi demokrasi berkeadaban. Pada tataran inilah pendidikan pesantren menduduki peran sangat instrumental. ${ }^{4}$

\section{Globalisasi dan Konstruksi Sosial Baru}

Revolusi teknologi dalam bidang komunikasi, informasi, dan transportasi dalam kehidupan masyarakat modern dewasa ini telah menjadikan tata kehidupan dunia semakin sempit dan terbuka lebar. Pola interaksi dan transaksi sosial pun mengalami perubahan yang drastis. Setiap orang dapat mengakses berita atau informasi dari belahan dunia manapun dalam waktu singkat. Masalah jarak, ruang, dan waktu bukan lagi menjadi sesuatu yang teramat problematik bagi setiap orang. Ada yang berpendapat bahwa seluruh umat manusia sedang menuju terbentuknya masyarakat paguyuban (gemeinschaf), karena mereka akan hidup dalam dunia yang semakin sempit dan menyatu, atau seperti digambarkan oleh David Harley, dunia menjadi global village (desa buana). Berbagai perkembangan baru menerobos masuk ke dalam lingkungan-lingkungan yang semula eksklusif dan tertutup. ${ }^{5}$

Keterbukaan dan kebebasan seakan telah menjelma menjadi takdir peradaban baru yang sulit bagi siapapun untuk menolaknya. Realitas keterbukaan dan kebebasan sebagai akibat perkembangan sains dan teknologi yang kemudian membawa kita memasuki suatu era baru yang dikenal dengan sebutan "globalisasi". Pada akhirnya globalisasi sebagai suatu proses sosial yang tak terelakkan akan membawa umat manusia di planet bumi ini menjadi suatu "world society" dan "global society" yang menurut Miriam L. Campanella diartikan sebagai "an idealistic cosmopolitan and universal society that includes all the people, living on earth, without regard to cultural and ethical beliefs" ${ }^{6}$

Menurut Fakih, proses globalisasi tersebut mencuat seiring pesatnya paham kapitalisme, yakni kian mengglobalnya peran pasar, investasi, dan proses produksi dari perusahaan-perusahaan transnasional, yang kemudian dikuatkan oleh ideologi dan tata dunia

${ }^{4}$ Azyumardi Azra, "Kebhinekaan, Multikulturalisme, dan Pendidikan Multikultural: Membangun Peradaban Indonesia Masa Depan”, Makalah disampaikan pada acara Seminar Nasional di UNISMA Malang 22 Februari 2014.

${ }^{5}$ Mun'im A. Sirry, Membendung Militansi Agama, Iman, dan Politik dalam Masyarakat Modern (Jakarta: Erlangga, 2003), 58.

6 Tarmizi Taher, "Islam dan Isu Globalisasi: Perspektif Budaya dan Agama", dalam M. Nasir Tamara dan Elza Peldi Taher, Agama dan Dialog Antar Peradaban (Jakarta: Paramadina, 1996), 175-176. 
perdagangan baru di bawah satu aturan yang ditetapkan oleh organisasi perdagangan bebas secara global. Hanya perlu dipahami bahwa globalisasi itu muncul bukan dalam konteks kehampaan, tetapi muncul bersamaan dan menjadi bagian fenomena runtuhnya pembangunan atau era pembangunanisme (developmentalism) di Asia Timur. $^{7}$

Teori pembangunan (developmentalisme) itu selain dikembangkan dalam rangka membendung pengaruh dan semangat antikapitalisme bagi berjuta-juta rakyat di Dunia Ketiga juga merupakan siasat baru kaum kapitalis untuk mengganti formasi sosial yang baru runtuh. Diskursus developmentalisme muncul pada tahun 1949, yakni saat presiden Harry S. Truman mengumumkan kebijakan pemerintahnya, dan sejak itu ia telah resmi menjadi bahasa dan doktrin kebijakan luar negeri Amerika Serikat. Developmentalisme dilontarkan dalam era perang dingin untuk membendung sosialisme, sehingga ia merupakan bungkus baru dari kapitalisme. ${ }^{8}$

Kecanggihan Barat, terutama kaum kapitalis, dalam menyosialisasikan dan meyakinkan Dunia Ketiga akan keampuhan paradigma pembangunanisme sebagai instrumen dalam proses perubahan sosial dari masyarakat tradisional menuju masyarakat modern sebagaimana yang telah dipraktikkan di Barat menjadikan paradigma ini diadopsi oleh hampir seluruh negara Dunia Ketiga, khususnya di Asia dan Afrika. Praktik pembangunan yang berorientasi pada pengejaran kemakmuran dan kesejahteraan meskipun dengan melakukan eksploitasi dan manipulasi baik sumber daya alam dan sumber daya manusianya telah menciptakan kemakmuran semu di Dunia Ketiga. Alhasil, hasil pembangunan hanya dinikmati oleh segelintir orang, mereka tiada lain adalah kelas kapitalis. Sebagai konsumen pembangunanisme, Dunia Ketiga tidak dapat mengejar ketertinggalannya dan memutuskan ikatannya dengan negara pusat dan mencapai perkembangannya yang penuh, sehingga dapat berdiri setara sebagai mitra, melainkan terperangkap dalam ketidakberdayaan dan ketergantungan (dependent) yang bersifat dominatif.

Lebih lanjut, praktik pembangunan di Dunia Ketiga selama ini juga telah menciptakan paradoks-paradoks baru berupa kesenjangan sosial, konflik sosial, penindasan, dan marginalisasi terhadap

7 Mansour Fakih, Jalan Lain Manisfesto Intelektual Organike (Yogyakarta: Pustaka Pelajar dan Insist, 2003), 198.

${ }^{8}$ Ibid., 200. 
masyarakat lemah, yang pada akhirnya berujung pada instabilitas dan krisis ekonomi, sosial, dan politik. Kini, Dunia Ketiga pun telah mengalami peristiwa krisis pembangunan. Kapitalisme di Dunia Ketiga yang selama ini dijadikan teladan keberhasilan pembangunan dan keberhasilan kapitalisme telah mengalami kebangkrutan. Banyak orang yang meramalkan bahwa era krisis pembangunan Dunia Ketiga adalah pertanda berakhirnya era developmentalisme, suatu proses perubahan sosial pasca-Perang Dunia Kedua yang dibangun di atas landasan paham modernisasi. ${ }^{9}$

Developmentalisme dengan konstruksi sosialnya di Dunia Ketiga boleh berakhir, tetapi dominasi dan eksploitasi kaum kapitalis atas negera-negara berkembang terus berkelanjutan, bahkan semakin canggih. Globalisasi tiada lain merupakan mode of domination baru, penerus ideologi penindasan developmentalisme. Keduanya memiliki watak yang sama, yakni sama-sama dominatif, hegemonik, dan eksploitatif atas sesama umat manusia yang memiliki posisi lemah. Bedanya, kalau developmentalisme (pembangunanisme) cenderung menekankan pada pertumbuhan ekonomi nasional dan memanfaatkan negara sebagai instrumen penindasannya. Oleh karena itu, selama era pembangunanisme Dunia Ketiga ditandai oleh praktik-praktik otoritarianisme yang dilakukan negara. Dunia Ketiga dipaksa untuk menjadi bagian dari pertumbuhan ekonomi global, di mana aktoraktornya bukan hanya negara melainkan juga perusahaan transnasional (TNCs), bank-bank transnasional (TNBs), dan lembaga keuangan multilateral seperti Bank Dunia dan International Monetary Fund (IMF), serta birokrasi perdagangan regional dan global seperti WTO, Nafta, Apec, ASEAN, dan semacamnya. Dengan demikian dapat dimengerti bahwa globalisasi sesungguhnya secara sederhana dipahami sebagai suatu proses pengintegrasian ekonomi nasional bangsa-bangsa ke dalam suatu sistem ekonomi global. ${ }^{10}$

Pada Abad ke-21 lembaga pendidikan dihadapkan pada tantangan era globalisasi yang memengaruhi perkembangan sosial budaya masyarakat Muslim Indonesia umumnya atau pendidikan Islam, termasuk pesantren, meskipun globalisasi menciptakan kecenderungan untuk peningkatan kerjasama internasional dan regional yang berusaha mewujudkan kemakmuran ekonomi, kemajuan ilmu pengetahuan dan teknologi, serta perubahan ekonomi

${ }^{9}$ Ibid., 208.

${ }^{10}$ Fakih, Jalan Lain, 211. 
masyarakat, namun tanpa disadari globalisasi telah menurunkan kualitas kepribadian manusia.

Posisi pesantren hari ini pun dihadapkan pada tantangan arus pendidikan global yang kapitalis-hedonis, di mana kompetisi antarindividu, antarnegara, dan antarusaha akan semakin tajam. Dunia secara global pada abad 21 ini telah memihak pada kepentingan pasar. Pada tahun 2003 yang lalu kita sudah memasuki era perdagangan bebas ASEAN yang secara formal telah diratifikasi dalam AFTA pada tahun 2010. Karena tahun 2020 mendatang akan memasuki era perdagangan bebas dalam konteks kerjasama Asia-Pasifik (APEC), maka pada milenium ketiga ini, kita berada dalam arus besar kehidupan yang berparadigma kapitalisme dan kondisi masyarakat yang akan menjadi rimba hedonisme (pengultusan kesenangan duniawi). ${ }^{11}$

\section{Dampak Globalisasi dalam Kehidupan Umat Beragama}

Era globalisasi yang sudah banyak merevolusi sistem kehidupan umat manusia sedikit banyak telah memunculkan dampak destruktif bagi keberlangsungan kehidupan manusia yang lebih humanis. Globalisasi yang memang dirancang menjadi mode of domination baru oleh kaum kapitalis Barat pada akhirnya menempatkan mereka sebagai aktor kunci yang memiliki posisi istimewa dan memainkan peran global dalam melakukan kontrol terhadap berbagai aspek kehidupan umat manusia baik dalam bidang ekonomi, politik, sains, teknologi, sosial, dan budaya. Dalam hal ini, Peter Beyer mengatakan bahwa "globalization is more than the spread of one historically existing culture at the expense of all others. It is also the creation of a new global culture with its attendant social structures, one which increasingly becomes the broader social context of all particular cultures in the world, including those of the West". ${ }^{12}$

Sebagai sistem dominasi baru, globalisasi ingin memercanggih proses eksploitasinya terhadap segenap potensi sosial masyarakat Dunia Ketiga. Prinsip dependensi yang selama ini mereka terapkan tentu terus dilembagakan melalui berbagai mekanisme perangkat instrumental globalisasi. Sebagaimana halnya modernisasi atau developmentalisme, globalisasi tidak pernah memberikan kesempatan bagi masyarakat Dunia Ketiga untuk otonom dan berdaya dalam

11 Kamaruddin Amin, et al., Quo Vadis Islamic Studies di Indonesia? (Jakarta dan Makassar: Diktis Kemenag RI dan PPs UIN Alauddin Makassar, 2006), 341.

12 Sirry, Membendung Militansi, 56. 
membangun masa depannya. Masyarakat terus dikontrol dan dimarginalisir sehingga mereka tetap berposisi sebagai negara-negara satelit yang harus tunduk patuh melayani kepentingan konsumtifnya negara-negara kapitalis.

Berbagai macam inovasi dalam bidang sains dan teknologi memang ditawarkan Barat kepada negara-negara Dunia Ketiga. Akan tetapi, tetap saja Dunia Ketiga tidak diberi kesempatan untuk dapat menguasai dan memroduksi sendiri guna kepentingan kehidupannya. Mereka hanya diposisikan sebagai konsumen antara produk-produk sains dan teknologi yang bahan bakunya sesungguhnya diambil secara eksploitatif dari negara-negara Dunia Ketiga. Pada saat masyarakat Dunia Ketiga beradaptasi, mengadopsi, dan memersiapkan diri untuk dapat memiliki keahlian dalam mengembangkan sains dan teknologi global, masyarakat Barat terus menciptakan produk-produk sains dan teknologi yang super canggih. Kondisi semacam inilah yang memaksa masyarakat Dunia Ketiga tidak akan pernah bisa keluar dari orbitnya sebagai objek pengonsumsi dan pengguna sains dan teknologi Barat.

Proses globalisasi yang sesungguhnya menawarkan prinsip-prinsip keterbukaan, kebebasan, dan pluralisme, namun praktiknya masyarakat Barat sebagai subjek globalisasi tidak memberikan kemerdekaan kepada masyarakat negara-negara Dunia Ketiga dalam berbagai aspek kehidupannya. Semua harus mengikuti dan patuh di bawah hegemoni logika pasarnya. Secara struktural, perangkat yang digunakan untuk melakukan dominasi dan hegemoni terhadap tatanan kehidupan sosial itu sudah disediakan dengan cukup baik. Oleh karena itu, berbagai perlawanan yang mencoba menggugat, mendekonstruksi, dan bahkan mencoba keluar dari logika globalisasi, akan berlawanan dengan struktur dominan tersebut.

Dalam melanggengkan sistem hegemoninya, globalisasi juga memanfaatkan berbagai nilai, pengetahuan, ideologi, dan media sebagai instrumental knowledge-nya. Nilai-nilai semacam sekularisme, dehumanisme, dan liberalisme merupakan seperangkat sistem nilai dominan guna mendomestikasikan nilai-nilai lokal untuk digantikan oleh nilai-nilai baru yang serba teknologis. Negara-negara Dunia Ketiga sebagai objek globalisasi yang masih kental dengan nilai-nilai humanisme, religiositas, dan spiritualitas jelas akan dihadapkan pada benturan yang luar biasa. Akibatnya, masyarakat Dunia Ketiga yang memiliki daya tawar rendah jelas mengalami keterguncangan. 
Harus pula diakui bahwa pada satu sisi globalisasi telah berhasil menciptakan perubahan-perubahan struktur sosial yang sulit untuk dielakkan dalam bidang ekonomi dan politik di mana struktur dalam bidang ini dapat menjadi global dan universal. Akan tetapi, nilai-nilai (values) apakah bersumber dari tradisi lokal dan agama dalam banyak hal berkaitan dengan realitas lokal, dan karena itu sulit untuk betulbetul menjadi universal. Menurut Azra, di sinilah akhirnya bisa terjadi konflik di antara budaya atau peradaban yang memiliki pretensipretensi global yang ekspansif dengan budaya lokal dan regional yang memiliki nuansa keagamaan tertentu. ${ }^{13}$

Dalam konteks persinggungan yang semakin terbuka antarkelompok sosial di berbagai belahan dunia dengan latar belakang perbedaan tradisi, budaya, dan peradaban, maka kemungkinan terjadinya konflik atau benturan antarperadaban (the clash of civilization) sebagai sesuatu yang meniscaya. Peradaban-peradaban yang berbeda memang memiliki komunalitas, afinitas, dan kesamaan. Tetapi, harus diakui, juga terdapat perbedaan-perbedaan yang potensial menimbulkan konflik, khususnya ketika berbagai perbedaan dieksploitasi untuk pemenuhan kepentingan-kepentingan tertentu. ${ }^{14}$

Oleh karena itu, proses globalisasi yang cenderung eksploitatif kemudian memunculkan berbagai macam konflik, kekerasan, dan bahkan peperangan dengan berbagai selubungnya seperti demokratisasi, HAM, terorisme dan lain sebagainya. Sebagaimana dimaklumi, eskalasi kekerasan dan konflik di belahan dunia global sekarang ini meningkat cukup tajam. Peningkatan kekerasan ini secara masif terjadi sejak akhir 1980, berikut dengan ambruknya Uni Soviet dan terpecahnya Eropa Timur. Tragedi 11 September 2001 dan peristiwa pengeboman baru-baru ini semakin menelanjangi realitas kekerasan yang ditimbulkan oleh globalisasi Barat. Pada tahap inilah nuansa keagamaan mulai membayangi konflik dan ketegangan global. ${ }^{15}$ Terlebih ketika umat Islam, terutama sayap radikalnya, secara sepihak kemudian disudutkan sebagai kelompok yang diidentifikasi harus bertanggung jawab terhadap serangkaian kekerasan global tersebut.

\footnotetext{
13 Azyumardi Azra, Konflik Baru Antar Peradaban: Globalisasi, Radikalisme, dan Pluralisme (Jakarta: Rajawali Pers, 2002), 15.

14 Ibid., 15-16.

15 Ibid., 19-20.
} 
Dengan memojokkan Islam, Barat yang disponsori Amerika Serikat lantas mengambil tindakan praksis berupa perang suci melawan terorisme global. Sasaran utamanya tiada lain adalah kelompok Islam yang menganut haluan keras seperti Jemaah Islamiah (JI) dan Al-Qaidah, bahkan negara yang dinilai sebagai pengekspor kaum militan seperti Irak pun dihancurkan dengan kekuatan fisik. Semua negara di belahan dunia tidak ketinggalan juga diinstruksikan untuk memerangi dan membendung berkembangnya sel terorisme yang bernuansa agama (Islam). Kondisi semacam ini menjadikan umat Islam berada dalam ketakutan dan merasa terpojok karena dituduh sebagai bagian dari agama "teroris" dan "ekstremis".

Peperangan kontra terorisme global yang disponsori Barat tidak lantas meredakan ketegangan dan mampu menciptakan tatanan formasi sosial baru nir-kekerasan. Secara kontradiktif, gerakan pembasmian terorisme justru memunculkan kontra-konflik yang tidak kalah dahsyatnya, terutama dari kelompok Islam yang berhaluan radikal. Dalam konteks inilah, sesungguhnya gerakan radikalisme Islam muncul sebagai counter culture terhadap globalisasi Barat. Akbar S. Ahmed, dalam bukunya Islam sebagai Tertuduh menjelaskan bahwa kekerasan dan terorisme yang marak pada dekade sekarang merupakan implikasi kompleks dari globalisasi yang cenderung menguntungkan Barat dan mengancam serta merugikan negara Dunia Ketiga yang notabene negara-negara dengan mayoritas berpenduduk Muslim. Globalisasi telah meluluhlantakkan 'asabîyah (kohesi sosial) sebagal identitas peradaban Dunia Ketiga, dan memunculkan asabîah berlebihan dalam bentuk tindakan-tindakan kekerasan dari skala yang kecil hingga skala yang sangat besar. ${ }^{16}$

Di samping itu, munculnya aneka tindakan kekerasan atas nama agama seperti gerakan radikalisme, militan, dan fundamentalisme Islam tidak bisa dilepaskan pula dari kondisi ketidakberdayaan dan kefrustrasian. Terkait dengan politik identitas, Azra menegaskan bahwa dampak nyata dari globalisasi adalah munculnya peningkatan politics of identity and representation di kalangan hampir seluruh masyarakat dunia. Kemunculan wacana tentang crusade dan jihad merupakan bentuk-bentuk terjelas dari politik identitas dan

16 Ahmad Rifa'i, "Islam sebagai Kambing Hitam”, dalam www.mediaindonesia.com /02-02-2004/Diakses 21-09-2010. 
representasi yang masih kuat tertahan, khususnya antara Barat dan Islam. ${ }^{17}$

\section{Rekam Jejak Pondok Pesantren Ngalah}

Pondok Pesantren Ngalah dari sisi usia memang tak terlalu tua, namun progress pesantren tersebut dari waktu ke waktu mampu melampaui pesantren lain yang lebih tua. Pesantren yang dikenal dengan sebutan Pondok Ngalah merupakan salah satu pesantren yang bertempat di Desa Sengonagung Kecamatan Purwosari Kabupaten Pasuruan. Pondok Ngalah didirikan oleh K.H. Moh. Sholeh Bahruddin Kalam pada 30 Agustus 1985 Masehi atau bertepatan dengan Jumat Pahing 14 Dzulhijjah 1405 Hijriyah. Sama halnya dengan pesantren yang lain, Pesantren Ngalah juga mempunyai historiografi yang panjang. ${ }^{18}$

Berawal dari ritual tarekat manjing suluk, Kiai Sholeh terinspirasi dan mendapat amanah dari seorang mursyid K.H. Munawir dari Kertosono dan ayahanda Kiai Sholeh untuk mendirikan pondok pesantren. Kiai Sholeh dengan segala komitmen dan integritas yang dimiliki diperintahkan mencari tempat untuk mendirikan pesantren. Dalam perjalannnya mencari lokasi pesantren, Kiai Sholeh menghadapi berbagai hambatan dan rintangan. Tepat pada tahun 1984 Kiai Sholeh berhasil menemukan lokasi sebagai cikal bakal berdirinya Pesantren Ngalah sesuai yang diharapkan guru dan orang tuanya.

Dari sinilah beliau memulai masa perjuangan dan menatap masa depannya dengan mendirikan pesantren yang sangat sederhana. Tepat pada hari Jumat Pahing bersamaan dengan pelaksanaan salat Jumat, Pondok Pesantren Ngalah diresmikan oleh K.H. Bahruddin Kalam yang disaksikan oleh beberapa ulama, pemerintah, dan masyarakat sekitar. Ulama yang hadir pada saat itu di antaranya adalah K.H. Munawir (Kertosono Nganjuk Jawa Timur), K.H. Abu Amar (Pasrepan Pasuruan Jawa Timur), K.H. Sirajuddin (Purwosari Pasuruan Jawa Timur) dan perwakilan ulama Sidogiri yang membawa pesan dari K.H. Nawawi bahwa beliau merestui atas berdirinya Pondok Pesantren Ngalah. Tidak hanya itu, selang beberapa hari setelah peresmian tersebut, K.H. Ahmad Muthohar (Mranggen

17 Azra, Konflik Baru Antar Peradaban, 21.

18 Sholeh Bahruddin, Wawancara, Pasuruan, 8 Agustus 2013. Beliau adalah Pengasuh Pondok Pesantren Ngalah dan Pendiri Universitas Yudharta Pasuruan yang senantiasa berupaya mengembangkan nilai-nilai multikultural. 
Semarang Jawa Tengah), pengarang beberapa kitab klasik sekaligus guru Kiai Sholeh, datang untuk merestui berdirinya Pondok Pesantren Ngalah. ${ }^{19}$

Setelah Pondok Pesantren Ngalah diresmikan, Kiai Sholeh memiliki beberapa santri yang dibawa dari pondok ayahnya di Carat Gempol, Pasuruan. Karena pada saat itu belum ada gutean (tempat semacam asrama untuk istirahat santri), maka gutean dibangun seadanya dari bambu. Kemudian pada tahun 1986 dengan bantuan masyarakat sekitar berdiri bangunan berlantai dua dengan jumlah empat kamar sebagai tempat tidur santri putra yang kemudian disebut asrama A (A.1 A.2 A.3 A.4) dan kini beralih menjadi A.1 A2 dan A.8 A. $9 .^{20}$

Dalam sejarah perkembangannya, Pesantren Ngalah mengalami kemajuan yang cukup signifikan. Hal ini ditandai dengan bertambahnya santri dari setiap tahunnya. Sampai saat ini Pesantren Ngalah memiliki kurang lebih 3000 santri (terhitung data bulan Muharram $1435 \mathrm{H}$ ). Di samping mengaji di pesantren, para santri juga belajar di sekolah formal dengan mengikuti kurikulum sekolah yang ditetapkan pemerintah. Di Pesantren Ngalah terdapat sekolah formal untuk semua jenjang pendidikan, mulai dari TK, Madrasah Ibtidaiyah (SD), Madrasah Tsanawiyah, SMP (SLTP), Madrasah Aliyah, SMA, SMK (SLTA), dan Universitas Yudharta Pasuruan. ${ }^{21}$

\section{Respons Kiai dan Pesantren terhadap Globalisasi}

Dampak dari proses globalisasi tersebut merembes hampir ke seluruh elemen sosial, tidak terkecuali kiai dan pesantrennya. Untuk melihat bagaimana respons kiai dan pesantren terhadap dampak globalisasi tersebut dapat dianalisis dari respons yang dilakukan oleh umat Islam. Seorang kiai menjadi tokoh sentral pesantren, dan pesantren itu sendiri merupakan tempat persemaian spiritual, religiositas, intelektual, dan kultural umat Islam. Pesantren juga menjadi ajang persemaian umat dalam membangun gerakan perubahan sosial. Dari berbagai analisis pakar, dapat dipahami bahwa respons umat Islam terhadap globalisasi itu tidak tunggal, melainkan plural. Ada yang melihat proses globalisasi sebagai ancaman yang menakutkan, sehingga mutlak untuk dinegasi tanpa reservasi. Namun ada sebagian yang melihat globalisasi tidak sekadar negatif dari yang

\footnotetext{
19 Ibid.

${ }^{20}$ Ibid.

21 Ibid.
} 
ditimbulkannya, melainkan globalisasi dipandang juga memiliki sisi positif. Sebagai realitas sosial, proses globalisasi tidak bisa ditolak begitu saja, ia dianggap sebagai tantangan baru yang perlu mendapatkan jawabannya secara konstruktif dari umat beragama. Semua ini berpulang pada cara pandang dan atau paradigma ideologi umat Islam.

Menurut Sirry, respons umat (agama) terhadap proses globalisasi terbagi ke dalam dua kelompok yang seolah saling berlawanan. Agama dapat merambah dunia global atau justru menentangnya. Yang disebut pertama adalah jalan universalisme, yaitu pandangan kultural yang menegaskan bahwa kita semua berada dalam kebersamaan dan kita lebih baik belajar dari satu sama lain sehingga dapat menjalin bekerjasama. Hal ini dapat melibatkan ragam kultural yang pada akhirnya mengantarkan umat beragama pada kesatuan kemanusiaan sebagai suatu keluarga. ${ }^{22}$

Namun demikian, ada sebagian umat yang merespons globalisasi secara emosional dan reaktif sebagaiamana respons umat Islam yang diidentifikasi ke dalam gerakan Islam radikal, Islam fundamentalis, dan Islam militan. Mereka sering mengklaim bahwa dirinya "berbeda" dan cara beragamanya yang paling benar. Secara sosiologis, munculnya respons semacam ini dikarenakan konstruksi atau struktur sosial hegemonik yang menjadikan mereka semakin tidak berdaya untuk melakukan perlawanan secara rasional. Di balik semua klaim itu, sebenarnya yang ada hanyalah ketidakmampuan mereka membendung arus globalisasi. ${ }^{23}$ Sebagaimana ditegaskan Nurcholis Madjid bahwa gejala tumbuhnya fundamentalisme itu bukanlah faktor ideologis semata, melainkan sosial psikologis. ${ }^{24}$ Jadi, sebetulnya ada perasaan tidak berdaya menghadapi Barat yang menimbulkan reaksi fundamentalistis. Hampir semua kasus radikalisme keagamaan menunjukkan bahwa kemunculan mereka senantiasa berhadapan dengan Barat. ${ }^{25}$

\footnotetext{
22 Sirry, Membendung Militansi, 60.

${ }^{23}$ Ibid., 60-61.

24. Nurcholish Madjid, Islam Agama Kemanusiaan Membangun Tradisi dan Visi Baru Islma Indonesia (Jakarta: Paramadina, 1995), 132-133. Lihat juga Nurcholish Madjid, Dialog Keterbukaan Artikulasi Nilai Islam dalam Wacana Sosial Politik. Kontemporer (Jakarta: Paramadina, 1998), 277.

25 Tarmizi Taher, Agama Kemanusiaan, Agama Masa Depan: Kontekstualisasi Kritis Doktrin Agama dalam Pembangunan dan Percaturan Global (Jakarta: Grafindo, 2004), 131.
} 
Oleh karena itu, pilihan yang diambil kaum fundamentalis tidak ada jalan lain kecuali mengartikulasikannya lewat gerakan radikalisme dengan mengatasnamakan agama. Kondisi semacam ini didukung pula oleh pola pemahaman atau cara pandang keagamaan mereka yang cenderung tekstualis, literalis, dan skripturalis. Atau menurut M. Amin Abdullah, sebuah cara pandang yang hanya menggunakan pendekatan teologis in the old sense. ${ }^{26}$ Salah satu komponen model pemikiran seperti ini adalah truth claim, dan bukan historical approach. Cara pandang keagamaan ini menempatkan teks agama dominan atas realitas sosial yang berkembang. Karena itu, ketika terjadi ketimpangan realitas sosial yang bertolak belakang dengan teks keagamaan, mereka pun mencoba merubahnya agar realitas tersebut selaras dengan teks agama, meskipun semua itu harus ditempuh lewat kekerasan. Bahkan, kelompok-kelompok fundamentalis ini mampu mengembangkan kekuatan sosial baru seperti terorisme bersenjata mutakhir sebagai cara merevitalisasi sejarah yang mereka dambakan (imaging history). Dengan tepat Bayer menggambarkan kecenderungan fundamentalis agama ini dengan frase "a fundamentalist's response that allows change under the insistence that nothing fundamental is changing". ${ }^{27}$

Sementara itu, Fakih memetakan paradigma ideologi umat Islam dalam merespons globalisasi ke dalam empat paradigma, yaitu: paradigma tradisionalis, modernis, revivalis, dan transformatif. Pertama, paradigma tradisionalis memandang bahwa kemiskinan, marginalisasi, dan ketidakberdayaan yang menimpa umat Islam itu semata-mata karena kehendak Tuhan, bukan karena ketidakadilan struktur sosial yang diakibatkan misalnya globalisasi. Hanya Tuhan yang Maha Tahu akan arti dan hikmah di balik ketentuan tersebut. Masalah kemiskinan dan ketidakberdayaan umat seringkali dipahami sebagai ujian dari Tuhan atas keimanan mereka. Seperti dimaklumi, akar teologis paradigma ini bersandar konsep Sunni (Ahl al-Sunnah wa al-Jamâ'ah) mengenai predeterminisme ketentuan dan rencana Tuhan yang telah ditetapkan sejak zaman azali. Dalam teologi Sunni, terutama aliran Ash'arîyah, manusia memang tidak mencipta sejarah mereka sendiri. Meskipun manusia didorong untuk berusaha, pada akhirnya Tuhan jualah yang menentukan. ${ }^{28}$

${ }^{26}$ M. Amin Abdullah, "Islam di Indonesia Lebih Pluralistik dan Demokratis", Ulumul Qur'an: Jurnal Ilmu dan Kebudayaan, Vol. 6, No. 3 (1995), 74.

27 Sirry, Membendung Militansi, 61.

28 Mansour Fakih, "Islam, Globalisasi, dan Nasib Kaum Marjinal", Ulumul Qur'an: Jurnal Kebudayaan dan Peradaban, Vol. 7, No. 6 (1997), 10-14. 
Kedua, paradigma modernis yang memahami masalah kemiskinan dan keterbelakangan atau suatu realitas sosial dalam kehidupan umat beragama pada dasarnya berakar pada persoalan "ada yang salah dari sikap mental, budaya ataupun teologi umat beragama". Pada dasarnya, kaum modernis memiliki pendekatan dan analisis yang sama dengan penganut paham modernisasi sekuler yang menjadi aliran mainstream dalam ilmu sosial dan yang dianut oleh aparat developmentalisme. Bagi mereka, ketidakberdayaan umat dikarenakan ketidakmampuan mereka berpartisipasi aktif dalam pembangunan dan globalisasi. Lebih dari itu, umat beragama perlu memahami bagaimana nilai-nilai moderat dapat ditransformasikan dengan mengedepankan toleransi dan harmonisasi dalam beragama, berbangsa, dan bernegara, ${ }^{29}$ sehingga mereka cenderung memahami nilai-nilai sikap mental, kreativitas, budaya, dan paradigma teologi sebagai pokok permasalahan yang harus diselesaikan, serta tidak melihat struktur kelas, gender, dan sosial sebagai pembentuk nasib umat. Dalam melihat realitas semacam itu, maka solusi yang kemudian mereka tawarkan di antaranya adalah rekonstruksi teologi yang tidak relevan dengan developmentalisme, memersiapkan SDM yang cocok dengan globalisasi, dan mendorong umat berpartisipasi aktif dan mampu bersaing dalam proses industrialisasi, pembangunan, dan globalisasi.

Ketiga, paradigma revivalis yang melihat baik ke dalam (internal factors) maupun ke luar (external factors) sebagai faktor penyebab ketidakberdayaan umat. Dalam kacamata mereka, ketidakberdayaan umat lebih disebabkan semakin banyak umat yang justru memakai ideologi atau isme lain ketimbang al-Qur'ân dan Hadîth sebagai dasar pijakan. Padahal, keduanya merupakan sumber ajaran Islam yang telah memuat petunjuk secara komplit, jelas dan sempurna sebagai fondasi bermasyarakat dan bernegara. Globalisasi dan kapitalisasi bagi mereka dianggap sebagai agenda Barat dan konsep non-Islami yang dipaksakan pada masyarakat Muslim. Oleh karena itu, mereka senantiasa melakukan resistensi terhadap setiap proses globalisasi dengan cara menerbitkan buku, menghimpun dan mengorganisir kelompok diskusi militan di kampus-kampus, menciptakan simbol resistensi, dan sering pula resistensi diartikulasi-kan dengan cara kekerasan fisik yang sangat transparan.

${ }_{29}$ Ms. Esti Andayani, "Meneguhkan Kembali Nilai-nilai Islam Moderat”, Konferensi Internasional: Konsolidasi Jaringan Ulama Internasional di Pondok Pesantren Salafiyah Syafi'iyah Sukorejo Situbondo Jawa Timur, 29-30 Maret 2014 
Keempat, paradigma transformatif yang memahami ketidakberdayaan umat disebabkan oleh ketidakadilan sistem dan struktur ekonomi, politik, dan kultur yang dominatif. Oleh karena itu, agenda mereka adalah melakukan tansformasi terhadap struktur melalui penciptaan relasi yang secara fundamental baru dan lebih adil dalam bidang ekonomi, politik, dan budaya. Secara praksis, agenda ini diartikulasikan dalam bentuk pencarian akar teologi, metodologi, dan aksi yang memungkinkan terjadinya transformasi sosial, pemihakan terhadap kaum miskin dan tertindas yang didasarkan pengkajian pada al-Qur'ân dan sekaligus analisis kritis terhadap struktur yang ada. Dalam hal ini, Islam dipahami sebagai teologi atau agama pembebasan bagi yang tertindas, serta mentransformasikan struktur sosial eksploitatif akibat globalisasi menjadi sistem sosial yang adil.

Dari berbagai paradigma pemikiran keagamaan di atas, dapat dimengerti bahwa pola pemikiran Islam yang inklusif, dialogis, dan berwawasan transformatif merupakan paradigma ideologi keagamaan yang favourable bagi umat Islam dalam merespons globalisasi. Paradigma ideologi keagamaan semacam inilah yang seharusnya dimanfaatkan kiai dan pesantren dalam mengkonstruksi dakwah multikulturalnya dalam upaya pengembangan kerukunan agama dalam masyarakat plural. Bagaimana pun ide tentang pluralitas termasuk prinsip dasar dalam Islam. Pluralisme Islam secara terus menerus dapat ditransformasikan ke dalam pluralisme modern. Pluralisme di sini dipahami sebagai suatu pertemuan yang sejati dari keserbaragaman dalam ikatan-ikatan kesopanan (bonds of civility)..$^{30}$

Dalam konteks ini, dakwah multikulturalisme secara sederhana dapat dipahami sebagai gerakan pemikiran yang moderat dan aksi keagamaan yang berusaha menyadarkan, mencerahkan, dan membebaskan umat dari pemahaman keagamaan eksklusif menuju pemahaman yang inklusif. Sebuah pemahaman yang dapat mengakui dan menghargai perbedaan, toleran, mampu hidup berdampingan dalam satu kehidupan sosial yang plural, karena Islam adalah agama moderat yang senantiasa mengajarkan keadilan, menerima keberagaman sebagai suatu keniscayaan. ${ }^{31}$ Lewat dakwah

${ }^{30}$ Nurcholish Madjid, "Pluralisme Agama di Indonesia", Ulumul Qur'an: Jurnal Ilmu dan Kebudayaan, Vol. 6, No. 3 (1995), 66.

31 Wahbah al-Zuhaylî, "Meneguhkan Kembali Nilai-nilai Islam Moderat", Konferensi Internasional: Konsolidasi Jaringan Ulama Internasional di Pondok Pesantren Salafiyah Syafi'iyah Sukorejo Situbondo Jawa Timur, 29-30 Maret 2014. Bandingkan dengan hikmah Q.S. al-Baqarah [2]: 143. 
multikultural, umat diharapkan memiliki visi religius yang akan berlaku adil terhadap agama mereka sendiri dan lugas terhadap agama yang dimiliki komunitas lain, dengan sebuah kesadaran yang positif tentang adanya perbedaan-perbedaan antara berbagai kelompok. ${ }^{32}$ Kesadaran akan keragaman inilah yang dapat dijadikan common platform bagi umat beragama untuk memerkuat formasi sosial civil society pluralis dalam melakukan counter hegemony globalisasi yang eksploitatif, dan mereformulasi tatanan formasi sosial yang lebih demokratis. Melalui cara pandang atau paradigma keagamaan semacam ini yang diartikulasikan dalam aksi sosial kritis berupa gerakan dakwah bercorak multikultural, kiai dan pesantren dapat menjawab tantangan dan sekaligus ancaman globalisasi neo-liberal sekarang ini.

\section{Upaya Pesantren Meredam Radikalisme Agama}

Perlu ada upaya bagaimana pesantren bukan sekadar berfungsi sebagai lembaga pendidikan agama, tetapi juga pesantren harus berperan aktif dalam membersihkan stigma negatif dan mereaktualisir kajian keislaman. Dalam berbagai kesempatan pesantren harus melakukan konstruksi kerukunan sosial untuk meredam radikalisme dan terorisme atas nama agama melalui aksi nyata, bukan sekadar penawaran ide-ide normatif. Secerdas apapun ide-ide yang dapat ditawarkan, tidak akan pernah berdampak secara konstruktif terhadap perubahan sosial manakala berhenti pada tataran wacana belaka. Ideide tentang pentingnya reposisi pemahaman agama sebagai moral sosial, ekonomi, dan politik; pencerahan civil society, rekonstruksi pemahaman agama umat, penguatan network antarelemen dan institusi sosial, secara praksis dapat diartikulasikan melalui pola-pola pendekatan, baik pendekatan proses yang lebih bersifat natural dan kultural, maupun pendekatan formal yang bersifat organisasional, asosiasional; struktural, dan pendekatan dialogis. Adapun aksi sosial yang dapat dilakukan pesantren sebagai lembaga pendidikan Islam adalah dengan melakukan penguatan konstruksi kerukunan sosial masyarakat yang humanis, toleran, inklusif, dan demokratis melalui langkah-langkah berikut ini.

Pertama, pesantren dituntut piawai dalam mereaktualisir kajiankajian keislaman yang mampu menyikapi persoalan saat ini, dengan mendukung akan perlunya fresh ijtihad (pemikiran yang segar) dan metodologi baru dalam ijtihad untuk menjawab permasalahanpermasalahan kontemporer, yang memungkinkan bisa diterapkan

32 Madjid, "Pluralisme Agama di Indonesia", 65. 
dalam metode bahth al-masâil yang selama ini menjadi ciri khas pesantren. Tentu persoalan yang diangkat dalam forum ini bisa diperluas dengan menganalisis dinamika dan perubahan sosial, baik pada ranah intelektual, moral, hukum, ekonomi atau teknologi, dapat direfleksikan dalam hukum Islam. Dengan demikian, kajian dalam forum bahth al-masâil tidak merasa terikat pada dogmatisme atau mazhab hukum dan teologi tertentu dalam pendekatan kajiannya yang selama ini sering terjadi. ${ }^{33}$

Kedua, pesantren harus lebih mendalami literatur sejarah peradaban Islam yang selama ini menjadi titik lemah, karena literatur kajian sejarah peradaban Islam di pesantren relatif masih dangkal. Tema-tema pembahasan lebih banyak dikonsentrasikan pada sejarah peperangan yang pernah dialami oleh Nabi, padahal ada banyak sisi lain sejarah peradaban Islam yang lebih luas ruang kajiannya daripada sekadar membahas sejarah peperangan, seperti kiprah Nabi selama di Madinah yang pernah merumuskan konsensus dengan penduduk Madinah yang beragama Kristen dan Yahudi yang kemudian dikenal dengan al-Mîthâq al-Madinah (Piagam Madinah). Munculnya piagam ini menjadi bukti konkret bagaimana Islam sangat menjunjung tinggi nilai-nilai pluralisme dan HAM, di mana dua prinsip pokok HAM dalam Piagam Madinah disebutkan bahwa: 1) semua umat adalah ummah wâhidah meskipun mereka berbeda suku antara yang satu dengan yang lain; dan 2) hubungan antara komunitas Muslim dan non-Muslim didasarkan pada prinsip-prinsip kesetaraan, berupa: interaksi secara baik dengan tetangga, saling membantu dalam menghadapi musuh bersama yang mengancam negara, membela mereka yang teraniaya baik itu pihak Muslim ataupun non-Muslim, menghormati kebebasan beragama yang dianut oleh masing-masing. ${ }^{34}$

Ketiga, kajian keislaman di pesantren perlu diperluas cakrawalanya, tidak hanya mendalami ilmu tauhid dan fiqh, tetapi pesantren juga dituntut mampu mengombinasikan atau mengintegrasikan secara kreatif warisan kesarjanaan Islam tradisional dengan pemikiran dan pendidikan Barat modern. Pesantren sangat memungkinkan untuk

33 Tren ini disebut Traditional Legalist yang banyak dijumpai dalam sistem madrasah di seluruh dunia Islam, misalnya di Timur Tengah, Afrika, sub-benua India dan kawasan Melayu (Indonesia, Malaysia). Kelompok ini disebut juga perawat ortodoksi karena mengacu pada hukum-hukum yang dikembangkan dan ditafsirkan oleh para ulama periode pra modern. Lihat Saeed, Islamic Thought, 142.

34 Bassam Tibi, Islam and The Cultural Accomodation of Social Change (Francisco: West View Press, 1991), 17-18. 
menyikapi isu-isu keadilan sosial, keadilan gender, HAM dan relasi yang harmonis antara Muslim dan non-Muslim. Senada dengan Omid Safi yang menyatakan bahwa saat ini umat Islam harus melakukan perubahan untuk mengatasi semua masalah yang ada di sekitarnya. Perubahan yang dilakukan harus berakar pada ajaran al-Qur'ân, sebagaimana dijelaskan dalam Q.S. al-Naḥl [16]: 90 "Inn Allâh ya'mur bi al-'adl wa al-iḥsân" [Sesungguhnya Allah memerintahkan berbuat adil dan berbuat kebaikan, serta mewujudkan keindahan (iḩsân)]. Berusaha untuk menjalankan perintah Ilahi mewujudkan keadilan ('ad), berbuat baik dan indah (iḩsân) yang menjadi jantung dari tradisi Islam. Meminjam istilah Dylan, inilah saat yang tepat berenang di air yang bergolak untuk menyelamatkan diri dan getaran tradisi Islam. Jika kita gagal melakukannya, kemanusiaan Muslim akan merosot mirip dengan karikatur kejahatan yang digambarkan oleh fanatisme dari sisi dalam (inside) dan sisi luar (outside) dari komunitas Muslim. ${ }^{35}$

Keempat, perlunya pesantren mengintensifkan dialog agama. Dialog agama dapat dilakukan secara personal, kultural, dan dapat pula dilakukan secara formal melalui berbagai forum keagamaan yang sudah ada. Secara personal dan kultural, tradisi dialog agama sudah dipraktikkan oleh beberapa pimpinan agama atau aktivis keagamaan. Aksi-aksi sosial keagamaan personal semacam ini sebagaimana pendapat Kim Knott merupakan bentuk upaya sinergi antara insider dan outsider ${ }^{36}$ untuk meminimalisir kecurigaan, sehingga ada rasa saling memahami secara objektif di antara kelompok lintas agama. Tentu hal ini dapat meredam radikalisme karena bentuk saling memahami di antara umat beragama dapat membangun jalinan sosial antarumat beragama.

Harus diakui aksi dialog keagamaan yang dilakukan beberapa pimpinan agama masih menuai pro-kontra, karena sebagian orang masih memandang tindakan semacam itu tidak lazim dalam paradigma normatif agama, padahal dialog agama bukan suatu studi akademis agama, dan bukan merupakan usaha untuk menyatukan semua ajaran agama menjadi satu. Dialog antarumat beragama bukan suatu usaha untuk membentuk agama baru yang dapat diterima oleh

35 Omid Safi, Progressive Muslim on Justice, Gender, and Pluralism (Oxford: Oneworld, 2003), 2.

${ }^{36}$ Kim Knott, "Insider/outsider Perspectives", dalam John R. Hinnels (ed.), The Routledge Companion to the Study of Religion (London: Routledge Taylor dan Fancis Group, 2005), 243. 
semua pihak, dialog agama bukan berdebat adu argumentasi antarumat beragama untuk mencari yang menang dan yang kalah. Dialog berupaya memberikan pemahaman dan pengertian tentang ajaran dan kehidupan. ${ }^{37}$

Intensifikasi dialog keagamaan penting dilakukan melalui forum dialog keagamaan yang sudah ada. FKUB (Forum Komunikasi Umat Beragama) dan FKKB (Forum Komunikasi Kesatuan Bangsa), yang sudah susah payah didirikan oleh komunitas sosial umat beragama keberadaannya perlu diruat dan diintensifkan sehingga tidak sebatas simbolik. Menurut TG. Taqiyuddin, sejauh ini keberadaan FKUB harus diakui banyak mengalami kemacetan. Tidak banyak anggota yang mau bergabung dan intens mengisi forum ini dengan berbagai kegiatan dialog intensif. Strategi intensifikasi forum semacam ini, benar apa yang dikatakan Kiai Sholeh, tidak serta merta dapat dilakukan secara inklusif khususnya kepada para anggotanya, melainkan harus bertolak dari kesadaran kultural masing-masing anggotanya. ${ }^{38}$ Bagi mereka yang sudah aktif dalam forum ini, sekecil apapun anggota yang aktif, sudah selayaknya tetap dilangsungkan, dalam artian jangan sampai fakum dari pertemuan dan kegiatan. Di samping itu, program-program kegiatannya perlu dirumuskan secara lebih kontekstual. Di samping itu, FKUB tidak mungkin jalan sendiri dalam proses dinamikanya, tetapi harus aktif menjalin hubungan baik dengan pemerintah daerah maupun antarorganisasi sosial lainnya. Tetapi yang lebih penting adalah FKUB ini tidak diorientasikan untuk kepentingan agama tertentu. ${ }^{39}$

Kelima, pesantren perlu mereaktualisir nilai dan moralitas kegamaan sebagai counter hegemony atas sistem sosial kontemporer yang sarat didominasi oleh ideologi neo-kapitalisme. lklim kehidupan sosial Indonesia yang dahulu masih sarat diwarnai oleh nilai-nilai dan moralitas keagamaan, kini sudah banyak mengalami pergeseran, bahkan perubahan drastis. Seiring menguatnya proses modernisasi dan globalisasi di masyarakat, maka life style, hubungan, dan jalinan sosial dalam kehidupan sosial sudah mulai diwarnai oleh ideologi neokapitalisme. Masyarakat dikenal terbuka (liberal) dalam mengadopsi ide-ide kultural yang berasal dari Barat yang ditawarkan melalui

${ }^{37}$ Burhanuddin Daya dan Herman Leonard Beck (eds.), Imu Perbandingan Agama di Indonesia dan Belanda (Jakarta: INIS, 1992), 208.

${ }^{38}$ Bahruddin, Wawancara, Pasuruan, 8 Agustus 2013.

39 Su'ud, Wawancara, Pasuruan pada tanggal 19 April 2013. Beliau adalah Ketua FKAUB (Forum Komunikasi Antar Umat Beragama) Kabupaten Pasuruan. 
perangkat modernisasi dan globalisasi. Perkembangan teknologi informasi seperti media cetak dan media elektronik, seperti televisi, internet, koran, majalah, dan sarana transportasi dan komunikasi, telah memercepat proses sosialisasi ideologi neo-kapitalisme.

Menguatnya perkembangan ideologi neo-kapitalisme global dalam konstruksi sosial masyarakat berarti semakin mereduksi sistem nilai yang bersumber dari agama. Kondisi ini apabila tidak direspons secara kritis oleh agama dapat berdampak serius terhadap disharmonisasi sosial. Karena itu, menyikapi arus modernisasi tersebut, Kiai Sholeh berpendapat bahwa proses modernisasi yang melanda masyarakat dewasa ini harus diimbangi dan direspons dengan nilai-nilai religiositas dan spiritualitas yang bersumber dari ajaran agama. Islam adalah agama yang rạmat li al-âlamin. ${ }^{40}$

Lebih lanjut Kiai Sholeh menegaskan bahwa revitalisasi nilai-nilai lokal tradisional, yang khususnya bersumber dari agama, perlu dihidupkan kembali. Elit agama perlu menekankan kepada masyarakat akan penting dan masih relevannya nilai-nilai tersebut guna menghantarkan kemaslahatan kehidupan umat manusia di dunia dan akhirat. Yang lebih penting lagi adalah bagaimana individu-individu umat beragama terutama pemimpinnya memberikan uswah hasanah dalam mengimplementasikan nilai dan moralitas agama dalam kehidupan masyarakat yang semakin sekuler dalam bidang sosial, ekonomi, dan politik. Apabila mereka mau dan mampu secara kreatif mengimplementasikan spiritualitas dan religiositas keagamaan dalam praktik kehidupan sosial, ekonomi, dan politik, misalnya, maka masyarakat yang sebagian masih menempatkan pemimpin agama pada posisi istimewa akan menjadikan apa yang dipraktikkan pimpinannya

Pada tataran praksis, usaha untuk merevitalisir nilai agama tidak hanya sebatas menghindarkan agama dari hegemoni ideologi neokapitalisme dengan cara menolaknya mentah-mentah. Revitalisasi penting dilakukan dengan cara menempatkan kembali agama sebagai basis moral kehidupan sosial masyarakat ini jelas tidak dapat dilakukan secara instruksional yang dogmatik. Secara kultural, agama melalui umatnya, khususnya elit-elitnya, harus aktif terlibat dan melibatkan diri mewarnai proses-proses sosial yang berlangsung dengan mengusung spirit agama. Dalam hal ini, pergulatan antara berbagai ide atau ideologi niscaya tidak dapat dihindarkan. Akan tetapi, semuanya harus dilalui umat beragama dengan tetap mengembangkan sikap

${ }^{40}$ Ibid, Wawancara, Pasuruan, 8 Agustus 2013. 
dialektis-kritis. Demikian pula, antarpemimpin agama atau organisasi keagamaan dituntut untuk terus menghidupkan kultur dialektika keagamaan di mana hasil dan reproduksi dialektika tersebut dapat ditransformasikan kepada umat. Kesibukan elit-elit tertibat dalam gesekan politik praktis perlu dialihkan kepada pemberdayaan publik agama.

Dalam konteks inilah, pencerahan keagamaan terhadap publik di masyarakat yang multikultural mutlak terus dilakukan, baik secara personal, kolektif, organisasional, maupun asosional, merupakan sebuah keniscayaan. Secara kultural, proses dapat dilakukan melalui pengembangan keterbukaan komunikasi dan dialog keagamaan antarpersonal dengan personal atau personal dengan kelompok sosial dengan memanfaatkan berbagai media yang ada seperti programprogram kegiatan lintas agama, Jemaah Yasinan, Jemaah Pengajian Ibu-ibu, Jemaah Manaqiban, forum Baḥth al-Masâil, dan berbagai perkumpulan sosial keagamaan lainnya. Yang tidak bisa dilupakan pula bahwa pencerahan umat dapat ditempuh pula melalui jalur pendidikan formal maupun non-formal. Bagi elit agama Islam, kiai dapat memaksimalkan fungsi lembaga pendidikan pesantren.

Keenam, pesantren dan kiai diharapkan mampu menghadirkan pola pendidikan yang berwawasan pluralisme dan multikulturalisme melalui media pendidikan formal maupun non-formal. Ide agar masyarakat yang plural secara agama dan multikultural secara budaya itu memiliki kearifan dalam menyikapi perbedaan, sehingga sangat berpotensi untuk didayagunakan sebagai modal pembangunan kerukunan sosial dapat diartikulasikan melalui jalur pendidikan baik formal dan nonformal. Di Indonesia sendiri terdapat banyak lembaga pendidikan formal baik agama maupun umum, mulai dari tingkat dasar sampai perguruan tinggi. Hal ini tentu merupakan satu kelebihan sendiri sebagai pintu masuk pentransformasian ide-ide keagamaan yang bersifat plural dan multikultural. Hampir setiap lembaga pendidikan formal, baik agama maupun umum pasti mengajarkan materi pendidikan agama. Hanya saja harus diakui sistem pendidikan dan pengajaran keagamaan demikian halnya dengan kurikulumnya yang diajarkan belum sepenuhnya memiliki wawasan pluralisme dan multikulturalisme. Seperti pesantren-pesantren yang berbasis Ahl alSunnah wa al-Jamâ'ah ala Nahdlatul Ulama, di mana visi dan misinya sangat mencerminkan sikap keberagamaan yang multikulturalistik dan pluralistik. Begitu juga tokoh sentralnya sudah mengamalkan 
religiositas yang multikulturalistik, namun harus diakui kesemuanya itu belum terimplementasikan secara gamblang dalam struktur kurikulum yang diajarkannya.

Demikian pula dalam lembaga-lembaga pendidikan non-formal seperti kiai, keluarga, dan semacamnnya juga belum banyak memberikan perhatian serius terhadap pentingnya wawasan pluralisme dan multikulturalisme dalam pendidikan keagamaan. Bahkan, tidak sedikit kiai di lapangan yang masih mengedepankan sistem pendidikan yang bersifat tekstual, dogmatik, dan normatif. Pola pendidikan semacam ini, baik secara langsung maupun tidak langsung, turut menciptakan peserta didik yang eksklusif dalam beragama. Dengan sistem pengetahuan agama yang dimilikinya, mereka tidak saja antipati terhadap perubahan yang ditimbulkan modernisasi dan globalisasi, tetapi juga tidak segan-segan berbuat radikal terhadap umat yang memiliki keyakinan dan kepercayaan lain.

Karena itu, memang dipandang penting pembumian ide pendidikan keagamaan yang berwawasan multikulturalisme. Secara praktis, ide ini dapat ditransformasikan dengan cara membangun komunikasi dan dialog dengan unsur kelembagaan pendidikan baik formal maupun non-formal untuk bersama-sama merekonstruksi sistem pengajarannya. Bahkan, secara empirik, K.H. Sholeh Bahruddin, salah seorang pengasuh pondok pesantren yang berlokasi di Senganagung Purwosari, membuka pesantrennya 24 jam penuh bagi penganut agama lain datang untuk belajar tentang Islam ataupun berdialog aneka persoalan berkaitan dengan agama. Menurutnya, beberapa orang dan sarjana teologi kerap datang bahkan mondok untuk belajar agama. Sebagaimana yang dituturkan pendeta Hadi bahwa gereja Kristen aktif mengundang Kiai Sholeh untuk berkhotbah di gerejanya ketika ada kebaktian ataupun acara-acara keagamaan lainnya. Pun demikian, para pendeta dan sarjana teologia juga aktif berkunjung bahkan nyantri di pondok pesantren yang dipimpin Kiai Sholeh.

Tawaran untuk merekonstruksi sistem pendidikan dan pengajaran keagamaan di berbagai lembaga pendidikan seperti kiai sudah saatnya tidak sekadar menerima dan mengajar santri yang beragama Islam. Apa yang dipraktikkan Kiai Sholeh merupakan contoh konkret sikap keterbukaan pesantren dalam mengembangkan kehidupan keagamaan yang plural dan multikultural. Oleh karena itu, diperlukan semacam 
pengembangan pendidikan pesantren sebagaimana dieksperimentasikan Kiai Sholeh.

Ketujuh, pesantren dan kiai dituntut berperan aktif dalam merevitalisir organisasi dan forum sosial-keagamaan. Tidak sedikit organisasi, asosiasi, dan forum keagamaan yang tumbuh dan berkembang di Pasuruan, antara lain: Nahdlatul Ulama, Muhammadiyah, PITI (Lembaga Dakwah Islam Indonesia), LDII (Persatuan Islam Tionghoa Indonesia), IPPNU, PMII (Pergerakan Mahasiswa Islam Indonesia), IRM (Ikatan Remaja Muslim), FKUB (Forum Komunikasi Umat Beragama), LSM (Lembaga Swadaya Masyarakat), Serumpun Bambu sampai Jemaah Yasinan, Jemaah Manaqiban, dan Majelis Zikir yang banyak bertebaran di hampir setiap RT dan RW di kelurahan masyarakat. Keberadaan organisasi dan asosiasi itu merupakan modal sosial strategis yang dapat didayagunakan untuk kepentingan pembangunan kerukunan sosial. Secara kultural, keberlangsungan organisasi keagamaan itu sudah berdampak konstruktif bagi reintegrasi masyarakat, namun demikian keberadaannya jelas perlu ditingkatkan kembali.

Samentara itu, beberapa organisasi besar di bawah naungan NU seperti IPNU (Ikatan Pelajar Putra Nahdlatul Ulama), IPPNU (Ikatan Pelajar Putri Nahdlatul Ulama), Ansor, Fatayat, Muslimat, ISNU (Ikatan Sarjana Nahdlatul Ulama), PMII, dan lainnya memang sudah concern mengembangkan agenda pemberdayaan masyarakat sipil di mana salah satu agendanya adalah penguatan kerukunan sosial. Kegiatan yang dilakukan tidak sebatas membangun dialog dan kemitraan antarumat beragama melainkan juga melakukan pendidikan inklusivitas keagamaan melalui media massa, radio, seminar dan workshop, akan tetapi organisasi-organisasi ini biasanya terkendala masalah pendanaan dan sumberdaya manusianya. Sebagai resolusinya, dari kalangan Kristen dan Hindu, misalnya, berharap pemerintah memberikan bantuan dana dalam menopang eksistensi kegiatan yang dilakukannya. Perlu disadari bahwa menggantungkan uluran dana dari pemerintah selama ini tidak cukup efektif. Pemberdayaan organisasi dapat dilakukan dengan cara memberdayakan sumber daya manusianya, sehingga mereka bisa kreatif dalam menciptakan peluang. Agenda praksis pemberdayaan semacam inilah yang sesungguhnya sekarang ini penting dilakukan guna memerkuat kembali posisi organisasi civil society ini. 
Kedelapan, pesantren dan kiai harus mampu melakukan penguatan network dan linkage dengan berbagai elemen, organisasi, institusi, dan asosiasi sosial lainnya. Persoalan ini merupakan kelemahan tersendiri yang dihadapi umat beragama sehingga menjadikannya marginal dan kurang mampu memainkan peran dalam proses pembangunan kerukunan sosial pada masyarakat yang multikultural. Di antara problematikanya adalah keterbukaan komunikasi dan kesadaran masing-masing pihak umat beragama dan elemen sosial masyarakat yang belum tumbuh dan berkembang secara baik. Karena itu, untuk dapat membangun network dan linkage yang kuat dibutuhkan keterbukaan komunikasi, dialog, kepercayaan, dan kesadaran bersama akan pentingnya pembangunan kerukunan sosial yang dinafasi oleh spiritualitas dan religiositas. Di sinilah agama harus memiliki kepedulian baik personal maupun kolektif dalam membangun kerjasama dan kemitraan guna kepentingan pembangunan konstruksi kerukunan sosial yang benar-benar humanis, inklusif, toleran, dan demokratis.

Dengan tawaran seperti disebutkan di atas, pesantren sebagai institusi pendidikan Islam yang mengajarkan kearifan sangat berperan dalam meluruskan pemahaman tentang ajaran Islam yang kental dengan nilai-nilai universal dan diharapkan dapat meluruskan kesalahpahaman masyarakat tentang istilah-istilah yang berkembang, misalnya dalam konteks ini adalah tentang jihad dan radikalisme.

\section{Penutup}

Pesantren Ngalah sebagai lembaga sosial keagamaan sejak didirikannya sampai saat ini dapat tetap eksis karena keberhasilannya mengembangkan pola kesinambungan dan kaderisasi. Radikalisme dalam pandangan Kiai Sholeh, sebagai pengasuh Pesantren Ngalah, didasari oleh kekeliruan dalam memahami teks al-Qur'ân maupun Hadith. Ide negara Islam yang selama ini menjadi pokok perjuangan kaum radikal, oleh Kiai Sholeh, dianggap tidak wajib, karena akan menemui jalan buntu. Dasar negara Pancasila menurut Pesantren Ngalah sudah final dan sejalan dengan ajaran Islam.

Pesantren Ngalah memiliki kedekatan dengan komunitas lintas agama, bahkan Kiai Sholeh sudah dua kali menggagas forum kerukunan antarumat beragama melalui seminar kebangsaan yang melibatkan tokoh-tokoh lintas agama se-Indonesia. Baru-baru ini Kiai Sholeh mendapatkan apresiai dari pimpinan pendeta se-Asia-Afrika termasuk pendeta dari Jerman atas inisiatif yang sudah dilakukan 
selama ini dalam menjalin kerukunan antarumat beragama di Indonesia.

Ada beberapa hal rekomendasi dari penulis yaitu: a) Pesantren Ngalah agar lebih pro-aktif dalam menyikapi fenomena radikalisme dengan menyosialisasikan pandangan-pandangannya ke masyarakat luas, karena masyarakat sangat membutuhkan pandangan para ulama; b) Strategi Pesantren Ngalah dalam merespons radikalisme dan pluralisme perlu mendapat dukungan khususnya pemerintah Kabupaten Pasuruan, sehingga dapat mengurangi kecenderungan radikalisme dalam beragama di kalangan masyarakat; dan c) Untuk memelihara kerukunan antarumat beragama pemerintah Kabupaten Pasuruan perlu memfasilitasi terjadinya komunikasi secara intens dengan berbagai paham dan keyakinan yang ada melalu Forum Kerukunan Umat Beragama (FKUB).

\section{Daftar Rujukan}

Abdullah, M. Amin. "Islam di Indonesia Lebih Pluralistik dan Demokratis", Ulumul Qur'an: Jurnal Ilmu dan Kebudayaan, Vol. 6, No. 3, 1995.

Amin, Kamaruddin, et al. Quo Vadis Islamic Studies di Indonesia?. Jakarta dan Makassar: Diktis Kemenag RI dan PPs UIN Alauddin Makassar, 2006.

Andayani, Ms. Esti. "Meneguhkan Kembali Nilai-nilai Islam Moderat", Konferensi Internasional: Konsolidasi Jaringan Ulama Internasional di Pondok Pesantren Salafiyah Syafi'iyah Sukorejo Situbondo Jawa Timur, 29-30 Maret 2014.

Azra, Azyumardi. "Kebhinekaan, Multikulturalisme, dan Pendidikan Multikultural: Membangun Peradaban Indonesia Masa Depan", Makalah disampaikan pada acara Seminar Nasional di UNISMA Malang 22 Februari 2014.

Azra, Azyumardi. Konflik Baru Antar Peradaban: Globalisasi, Radikalisme, dan Pluralisme. Jakarta: Rajawali Pers, 2002.

Bahruddin, Sholeh. Wawancara. Pasuruan, 8 Agustus 2013.

Daya, Burhanuddin, dan Beck, Herman Leonard (eds.). Ilmu Perbandingan Agama di Indonesia dan Belanda. Jakarta: INIS, 1992.

Fakih, Mansour. "Islam, Globalisasi, dan Nasib Kaum Marjinal", Ulumul Qur'an: Jurnal Kebudayaan dan Peradaban, Vol. 7, No. 6, 1997.

-----. Jalan Lain Manisfesto Intelektual Organik. Yogyakarta: Pustaka Pelajar dan Insist, 2003. 
----. Runtubnya Teori Pembangunan dan Globalisasi. Yogyakarta: Pustaka Pelajar dan Insist, 2002.

Knott, Kim. "Insider/outsider Perspectives", dalam John R. Hinnels (ed.),The Routledge Companion to the Study of Religion. London: Routledge Taylor dan Fancis Group, 2005.

Madjid, Nurcholish. "Pluralisme Agama di Indonesia", Ulumul Qur'an: Jurnal Ilmu dan Kebudayaan, Vol. 6, No. 3, 1995.

-----. Dialog Keterbukaan Artikulasi Nilai Islam dalam Wacana Sosial Politik Kontemporer. Jakarta: Paramadina, 1998.

-----. Islam Agama Kemanusiaan Membangun Tradisi dan Visi Baru Islma Indonesia. Jakarta: Paramadina, 1995.

Rabi', Ibrahim M. Abu. "Post-September 11 Critical Assement of Modern Islamic History", dalam 11 September: Religious Perspectives on the Causes and Consequences. England: Oneword Publications, 2002.

Rifa'i, Ahmad. "Islam sebagai Kambing Hitam", dalam www.mediaindonesia.com/02-02-2004/Diakses 21-09-2010.

Saeed, Abdullah. Islamic Thought: An Introduction. London dan New York: Routledge, 2006.

Safi, Omid. Progressive Muslim on Justice, Gender, and Pluralism. Oxford: Oneworld, 2003.

Sirry, Mun'im A. Membendung Militansi Agama Iman dan Politik dalam Masyarakat Modern. Jakarta: Erlangga, 2003.

Su'ud (Ketua Forum Komunikasi Antar Umat Beragama Kabupaten Pasuruan). Wawancara. Pasuruan pada tanggal 19 April 2013.

Taher, Tarmizi. "Islam dan Isu Globalisasi: Perspektif Budaya dan Agama", dalam M. Nasir Tamara dan Elza Peldi Taher, Agama dan Dialog Antar Peradaban. Jakarta: Paramadina, 1996.

-----. Agama Kemanusiaan, Agama Masa Depan: Kontekstualisasi Kritis Doktrin Agama dalam Pembangunan dan Percaturan Global. Jakarta: Grafindo, 2004.

Tibi, Bassam. Islam and The Cultural accomodation of Social Change. Francisco: West View Press, 1991.

Zuhaylî (al), Wahbah. "Meneguhkan Kembali Nilai-nilai Islam Moderat", Konferensi Internasional: Konsolidasi Jaringan Ulama Internasional di Pondok Pesantren Salafiyah Syafi'iyah Sukorejo Situbondo Jawa Timur, 29-30 Maret 2014. 